\title{
CORRELATING DENTAL CARIES WITH TOOTH BRUSHING FREQUENCY, TYPE OF TOOTHPASTE AND DENTAL VISITS
}

Vaibhav Munjal ${ }^{1}$, Ritu Jindal ${ }^{2}$, Rohini Dua ${ }^{3}$, Ripin Singh Garewal ${ }^{4}$, Parveen Bathla ${ }^{5}$

${ }^{1}$ Reader, Department of Pedodontic and Preventive Dentistry, National Dental College and Hospital, Dera Bassi, Punjab, India.

${ }^{2}$ Prof. \& Head, Department of Pedodontic and Preventive Dentistry, National Dental College and Hospital, Dera Bassi, Punjab, India.

${ }^{3}$ Professor, Department of Pedodontic and Preventive Dentistry, National Dental College and Hospital, Dera Bassi, Punjab, India.

${ }^{4}$ Lecturer, Department of Pedodontic and Preventive Dentistry, National Dental College and Hospital, Dera Bassi, Punjab, India.

${ }^{5}$ PG Student, Department of Pedodontic and Preventive Dentistry, National Dental College and Hospital, Dera Bassi, Punjab, India.

Corresponding Author: Parveen Bathla

Mobile: +91-08699805518 E-mail: dr.parveenbathla@gmail.com

Received: $25^{\text {th }}$ Jan. 2014 Accepted: $1^{\text {st }}$ April 2014 Online: $25^{\text {th }}$ May 2014

\section{ABSTRACT}

Aim: This study was done to evaluate correlation of Dental Caries status with frequency of tooth brushing, type of toothpaste and regular dental visits in children. Materials and methods: This cross-sectional study was carried out randomly on 2500 school children of two age groups viz. 12 and 15 years, and caries examination was done using WHO (World Health organization) 1997 criteria in order to correlate with various risk factors viz. brushing frequency, use of fluoridated/non-fluoridated toothpaste and frequency of child's visit to dental clinic. Results: In both the age groups brushing frequency and type of toothpaste used insignificantly affected caries while evidence that frequency of child's visit to dental clinic reduces caries risk was also not substantial. Conclusion: The present study implicates that due to complex multifactorial nature of dental caries, its prevention still remains an enigma for the dental professional and society.

Keywords: Dental caries, Tooth brushing, Tooth paste

\section{INTRODUCTION}

Dental Caries has been called as a scourge of modern civilization and no doubt it is considered as one of mankind's most prevalent chronic disease. ${ }^{1}$ Time and again dental caries has been correlated with various risk factors such as oral hygiene practices, fluoridation, regular visits to dentist, socioeconomic status and diet. In today's era, where dental care facilities have reached new heights, this study attempts to understand the complex multifactorial nature of dental caries and means to prevent it, which is still an ongoing challenge. ${ }^{2}$

\section{MATERIALS AND METHODS}

The present study was conducted in Ludhiana city on randomly selected 2,500 school children in the age groups of 12 and 15 years, after taking permission from local authorities, school administration and parents. Dental caries status was recorded using WHO index (1997) and a structured Questionnaire designed to elicit information regarding brushing frequency, type of toothpaste used (fluoridated or non fluoridated) and frequency of child's visit to dental clinic. Following groups were made according to tooth brushing frequency - Group 1: once daily; Group 2: twice or more daily. Based on type of tooth paste used - Group I: fluoridated; Group II: non fluoridated. Frequency of visit to dentist was grouped as - Group A: Regular visits (3months 12 months); Group B: Irregular visits (11/2 - 2 yrs) / in Emergency / Never (Table 1). According to data obtained, dental caries status in each group was correlated with individual risk factor using the student's $\mathrm{t}$ test.

Postage stamps depicting various aspects of radiologic science ranging from theoretical radiation physics to clinical 
Table 1: Grouping according to risk factors

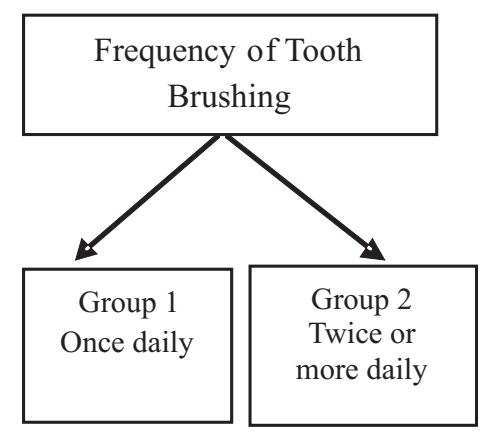

radiologic imaging and treatment are illustrated in this article.

\section{RESULTS}

The study examined 1,250 children in each of the two age groups viz. 12 years and 15 years

(Table 2).

The caries prevalence and status in individual risk factor group was compared.

In 12 year age group, caries prevalence recorded in Group 1 (once daily brushing) was $81.07 \%$, the scores being $0.84 \mathrm{deft}, 2.73$ DMFT, 1.14 defs and 3.53 DMFS, while in Group 2 (Twice or more daily brushing), it was observed to be $81.93 \%$ with $0.96 \mathrm{deft}, 2.76$ DMFT, 1.3 defs and 3.75 DMFS scores (Table 3). In 15 year age group, Group 1 reported $85.77 \%$ caries prevalence with 4.19 DMFT and 5.32 DMFS. In Group 2, it was 86.88\%, with 4.24 DMFT and 5.48 DMFS scores (Table 4).

Caries prevalence for 12 year olds in Group I (fluoridated toothpaste) was $81.72 \%$ with scores of 0.88 deft, 2.73 DMFT, 1.18 defs and 3.57 DMFS; and the caries prevalence in Group II (non fluoridated toothpaste) was observed to be $79.21 \%$, with $0.89 \mathrm{deft}$, 2.79 DMFT, 1.41 defs and 3.89 DMFS scores (Table 5). In 15 year age olds, the caries prevalence in Group I was found to be $86.34 \%$ with 4.26 DMFT and 5.41 DMFS scores. In Group II, it was observed to be
85.22\%, the scores being 3.96 DMFT and 5.22 DMFS (Table 6).

In 12 year age group, Group A children (Regular visits) showed $81.53 \%$ caries prevalence with 1.20 deft, 2.75 DMFT, 1.65 defs and 3.77 DMFS scores and Group B (irregular/emergency/never) had caries prevalence of 81.34\% with $0.86 \mathrm{deft}, 2.74$ DMFT, 1.17 defs and 3.6 DMFS scores (Table 7)

In 15 year age group it was $80.88 \%$ with 4.07 DMFT and 4.88 DMFS scores and $86.46 \%$ caries prevalence with 4.21 DMFT and 5.41 DMFS scores (Table 8).

Results of this study revealed a statistically insignificant difference in caries status with brushing frequency and type of toothpaste used. Results also show that frequency of dental visits does not affect dental caries status. Rather a negative correlation was seen in the 12 years age group between dental caries (deft) and regular dental attendance.

Table 2. Distribution of sample size

\begin{tabular}{|c|c|}
\hline Age group (years) & Total number of children (2500) \\
\hline 12 & 1250 \\
\hline 15 & 1250 \\
\hline
\end{tabular}


Table 3: Brushing frequency versus dental caries status in 12 year old age group

\begin{tabular}{|c|c|c|c|c|c|c|c|c|c|c|c|c|c|c|c|}
\hline \multirow[t]{2}{*}{$\begin{array}{l}\text { Brushing } \\
\text { frequency }\end{array}$} & \multirow{2}{*}{$\begin{array}{l}\text { Total no. } \\
\text { of children } \\
\text { examined }\end{array}$} & \multirow{2}{*}{$\begin{array}{c}\text { No. of } \\
\text { individuals } \\
\text { with caries }\end{array}$} & \multirow{2}{*}{$\begin{array}{c}\text { Caries } \\
\text { prevalence } \\
(\%)\end{array}$} & \multicolumn{3}{|c|}{ Deft } & \multicolumn{3}{|c|}{ DMFT } & \multicolumn{3}{|c|}{ defs } & \multicolumn{3}{|c|}{ DMFS } \\
\hline & & & & MEAN & \pm & S.D. & MEAN & \pm & S.D. & MEAN & \pm & S.D. & MEAN & \pm & S.D. \\
\hline $\begin{array}{l}\text { Group 1 } \\
\text { (Once daily) }\end{array}$ & 785 & 636 & 81.07 & 0.84 & \pm & 1.55 & 2.73 & \pm & 2.59 & 1.14 & \pm & 3.20 & 3.53 & \pm & 3.73 \\
\hline $\begin{array}{l}\text { Group } 2 \\
\text { (Twice or } \\
\text { More daily) }\end{array}$ & 465 & 381 & 81.93 & 0.96 & \pm & 1.63 & 2.76 & \pm & 2.43 & 1.33 & \pm & 3.52 & 3.75 & \pm & 3.81 \\
\hline
\end{tabular}

deft : Decayed, extracted, filled tooth, DMFT : Decayed, missing, filled tooth, defs : Decayed, extracted, filled tooth surfaces, DMFS : Decayed, missing, filled tooth surfaces, SD : Standard deviation

t values

\begin{tabular}{|c|c|c|c|c|}
\hline & deft & DMFT & defs & DMFS \\
\hline Once Daily and Twice or More & 0.30 & 0.20 & 0.98 & 1.00 \\
\hline
\end{tabular}

Table 4: Brushing frequency versus dental caries status in 15 year old age group

\begin{tabular}{|l|c|c|c|c|c|l|l|l|l|}
\hline $\begin{array}{l}\text { Brushing } \\
\text { frequency }\end{array}$ & $\begin{array}{l}\text { Total no. } \\
\text { of children } \\
\text { examined }\end{array}$ & $\begin{array}{c}\text { No. of } \\
\text { individuals } \\
\text { with caries }\end{array}$ & $\begin{array}{c}\text { 1 } \\
\text { prevalence } \\
(\%)\end{array}$ & \multicolumn{2}{|c|}{ DMFT } & \multicolumn{4}{c|}{ DMFS } \\
\hline & & & & MEAN & \pm & S.D. & MEAN & \pm & S.D. \\
\hline $\begin{array}{l}\text { Group 1 } \\
\text { (Once Daily) }\end{array}$ & 808 & 693 & 85.77 & 4.19 & \pm & 3.21 & 5.32 & \pm & 4.30 \\
\hline $\begin{array}{l}\text { Group 2 } \\
\text { (Twice or More) }\end{array}$ & 442 & 384 & 86.88 & 4.24 & \pm & 3.10 & 5.48 & \pm & 4.36 \\
\hline
\end{tabular}

DMFT : Decayed, missing, filled tooth, DMFS : Decayed, missing, filled tooth surfaces, SD : Standard deviation

\section{t values}

\begin{tabular}{|c|c|c|}
\hline & DMFT & DMFS \\
\hline Once daily and Twice or More & 0.25 & 0.60 \\
\hline
\end{tabular}


Table 5: Type of tooth paste versus dental caries status in 12 year old age group

\begin{tabular}{|c|c|c|c|c|c|c|c|c|c|c|c|c|c|c|c|}
\hline \multirow{2}{*}{$\begin{array}{l}\text { Type of } \\
\text { Toothpaste }\end{array}$} & \multirow{2}{*}{$\begin{array}{c}\text { Total } \\
\text { no. of } \\
\text { children } \\
\text { examined }\end{array}$} & \multirow{2}{*}{$\begin{array}{c}\text { No. of } \\
\text { individuals } \\
\text { with caries }\end{array}$} & \multirow{2}{*}{$\begin{array}{l}\text { Caries } \\
\text { prevalence } \\
(\%)\end{array}$} & \multicolumn{3}{|c|}{ deft } & \multicolumn{3}{|c|}{ DMFT } & \multicolumn{3}{|c|}{ Defs } & \multicolumn{3}{|c|}{ DMFS } \\
\hline & & & & & & & & & & & & & & & \\
\hline & & & & & & & & & & & & & & & \\
\hline $\begin{array}{l}\text { Group I } \\
\text { (Fluoridated) }\end{array}$ & 1072 & 876 & 81.72 & 0.88 & \pm & 1.59 & 2.73 & \pm & 2.51 & 1.18 & \pm & 3.34 & 3.57 & \pm & 3.70 \\
\hline $\begin{array}{l}\text { Group II } \\
\text { (Non Fluoridated) }\end{array}$ & 178 & 141 & 79.21 & 0.89 & \pm & 1.56 & 2.79 & \pm & 2.68 & 1.41 & \pm & 3.19 & 3.89 & \pm & 4.06 \\
\hline
\end{tabular}

deft : Decayed, extracted, filled tooth, DMFT : Decayed, missing, filled tooth, defs : Decayed, extracted, filled tooth surfaces, DMFS : Decayed, missing, filled tooth surfaces, SD : Standard deviation

t values

\begin{tabular}{|l|c|c|c|c|}
\hline & deft & DMFT & defs & DMFS \\
\hline $\begin{array}{l}\text { Fluoridated and } \\
\text { Non-Fluoridated }\end{array}$ & 0.08 & 0.29 & 0.86 & 1.05 \\
\hline
\end{tabular}

Table 6. Type of tooth paste versus dental caries status in 15 year old age group.

\begin{tabular}{|c|c|c|c|c|c|c|c|c|c|}
\hline $\begin{array}{c}\text { Type of } \\
\text { toothpaste }\end{array}$ & $\begin{array}{l}\text { Total no. of } \\
\text { children } \\
\text { examined } \\
\text { individuals } \\
\text { with caries }\end{array}$ & $\begin{array}{c}\text { No. of } \\
\text { prevalence } \\
(\%)\end{array}$ & \multicolumn{2}{|c|}{ DMFT } & \multicolumn{4}{|c|}{ DMFS } \\
\hline $\begin{array}{c}\text { Group I } \\
\text { (Fluoridated) }\end{array}$ & 1047 & 904 & 86.34 & 4.26 & \pm & 3.19 & 5.41 & \pm & 4.35 \\
\hline $\begin{array}{c}\text { Group II } \\
\text { (Non - Fluoridated) }\end{array}$ & 203 & 173 & 85.22 & 3.96 & \pm & 3.05 & 5.22 & \pm & 4.19 \\
\hline
\end{tabular}

DMFT : Decayed, missing, filled tooth, DMFS : Decayed, missing, filled tooth surfaces, SD : Standard deviation

t values

\begin{tabular}{|l|c|c|}
\hline & DMFT & DMFS \\
\hline $\begin{array}{l}\text { Fluoridated and Non } \\
\text { Fluoridated }\end{array}$ & 1.24 & 0.57 \\
\hline
\end{tabular}


Table 7: Frequency of visit to the Dental clinic versus dental caries status in 12 year old age group

\begin{tabular}{|c|c|c|c|c|c|c|c|c|c|c|c|c|c|c|c|}
\hline $\begin{array}{c}\text { Frequency } \\
\text { of visit }\end{array}$ & $\begin{array}{c}\text { Total } \\
\text { no. of } \\
\text { children } \\
\text { examined }\end{array}$ & $\begin{array}{c}\text { No. of } \\
\text { individuals } \\
\text { with caries }\end{array}$ & $\begin{array}{c}\text { Caries } \\
\text { prevalence } \\
(\%)\end{array}$ & \multicolumn{3}{|c|}{ deft } & \multicolumn{3}{|c|}{ DMFT } & \multicolumn{5}{c|}{ defs } & \multicolumn{3}{c|}{ DMFS } \\
\hline & & & & MEAN & \pm & S.D. & MEAN & \pm & S.D. & MEAN & \pm & S.D. & MEAN & \pm & S.D. \\
\hline $\begin{array}{c}\text { Group A } \\
\text { (Regular) }\end{array}$ & 103 & 84 & 81.53 & 1.20 & \pm & 1.81 & 2.75 & \pm & 2.37 & 1.65 & \pm & 3.45 & 3.77 & \pm & 4.12 \\
\hline $\begin{array}{c}\text { Group B } \\
\text { (Irregular/ } \\
\text { Emergency or } \\
\text { Never) }\end{array}$ & 1147 & 933 & 81.34 & 0.86 & \pm & 1.56 & 2.74 & \pm & 2.55 & 1.17 & \pm & 3.31 & 3.60 & \pm & 3.72 \\
\hline
\end{tabular}

deft: Decayed, extracted, filled tooth, DMFT : Decayed, missing, filled tooth, defs : Decayed, extracted, filled tooth surfaces, DMFS : Decayed, missing, filled tooth surfaces, SD : Standard deviation

\section{t values}

\begin{tabular}{|l|c|c|c|c|}
\hline & deft & DMFT & defs & DMFS \\
\hline Regular and Irregular/ Emergency/Never & $2.09 *$ & 0.04 & 1.41 & 0.44 \\
\hline
\end{tabular}

Table 8: Frequency of visit to the dental clinic versus status of dental caries in 15 year old age group

\begin{tabular}{|c|c|c|c|c|c|c|c|c|c|}
\hline \multirow[t]{2}{*}{$\begin{array}{c}\text { Frequency } \\
\text { of visit }\end{array}$} & \multirow{2}{*}{$\begin{array}{c}\text { Total } \\
\text { no. of } \\
\text { children } \\
\text { examined }\end{array}$} & \multirow{2}{*}{$\begin{array}{c}\text { No. of } \\
\text { individuals } \\
\text { with } \\
\text { caries }\end{array}$} & \multirow{2}{*}{$\begin{array}{c}\text { Caries } \\
\text { prevalence } \\
(\%)\end{array}$} & \multicolumn{3}{|c|}{ DMFT } & \multicolumn{3}{|c|}{ DMFS } \\
\hline & & & & MEAN & \pm & S.D. & MEAN & \pm & S.D. \\
\hline $\begin{array}{l}\text { Group A } \\
\text { (Regular) }\end{array}$ & 68 & 55 & 80.88 & 4.07 & \pm & 4.14 & 4.88 & \pm & 5.73 \\
\hline $\begin{array}{c}\text { Group B } \\
\text { (Irregular/ Emergency or } \\
\text { Never) }\end{array}$ & 1182 & 1022 & 86.46 & 4.21 & \pm & 3.11 & 5.41 & \pm & 4.23 \\
\hline
\end{tabular}

DMFT: Decayed, missing, filled tooth, DMFS: Decayed, missing, filled tooth surfaces, SD: Standard deviation

t values

\begin{tabular}{|l|c|c|}
\hline & DMFT & DMFS \\
\hline Regular and Irregular/ Emergency/Never & 0.35 & 0.98 \\
\hline
\end{tabular}




\section{DISCUSSION}

Dental Caries is considered as primary cause of pain and tooth loss. ${ }^{2}$ Decline in caries prevalence in developed countries has been associated with improved oral hygiene practices and several dental care preventive programs whereas in developing countries, higher caries prevalance is mainly because the oral health care systems focus on curative care. ${ }^{3}$

Although good oral hygiene habits especially tooth brushing, are believed to go a long way in preventing caries, the present study found no significant correlation between dental caries and brushing frequency. Studies conducted by Sheiham $(1977)^{4}$, Frandsen (1986) ${ }^{5}$, Mahalakshmi et al (2004) and Boka $\mathrm{V}$ et al (2013) ${ }^{7}$ also showed statistically insignificant difference in caries among children brushing once or twice daily. Moreover, Gibson and Williams (1999) ${ }^{8}$ concluded 'for children who brushed their teeth twice a day or more, consumption of sugars and sugary foods did not appear to be associated with caries'.

However, studies have demonstrated that stated brushing frequency is inversely related to the prevalence of plaque (Tucker et al $1976^{9}$, Leske et al 1976). ${ }^{10}$ Javali et al (2004) ${ }^{11}$, Gupta R et al $2013^{12}$ and Lakhanpal $\mathrm{M}$ et al (2013) ${ }^{1}$ reported that prevalence of caries increases significantly in those who do not clean their teeth regularly. According to Wei and Hyman ${ }^{13}$, most children do not brush long enough and with proper technique to achieve total deplaquing.

No significant correlation was established between dental caries and use of fluoridated / non-fluoridated toothpaste. This maybe because most of the children in the sample in both age groups used fluoridated toothpaste and therefore, a very low number of cases of non-fluoridated toothpaste were available for comparison.

A large number of clinical trials viz. Murray and Rugg Gunn (1991) $)^{14}$, Marthaler (1984) $)^{15}$ and Renson et al $(1985)^{16}$ have suggested that the large caries reduction reported in many countries may be related to regular use of fluoride dentifrices. Boka V et al (2013) ${ }^{7}$ concluded that significant correlation is present between visible dental plaque and brushing with fluoridated toothpaste.

According to Pader $(1988)^{17}$, plaque removal efficacy depends upon efficient tooth brushing and not on whether a dentifrice is used or not. Therefore, a pertinent question is whether tooth cleaning with a non therapeutic dentifrice provides a caries prophylactic effect. Results from studies on self-performed oral hygiene and dental caries indicate that neither brushing frequency nor oral cleanliness effects caries development significantly when non-fluoridated dentifrices are used (Bellini et al, 1981). ${ }^{18}$

The results of the present study also show that frequency of dental visits does not affect dental caries status. Rather a negative correlation was seen in the 12 years age group between dental caries and regular dental attendance. This could probably be because the number of regular attenders obtained from the sample in both age groups was very low as compared to irregular/emergency or never group. Reasons for visiting were curative rather than preventive.

On the contrary, Chaudhry et al (1957) ${ }^{19}$ and Miglani et al $(1970)^{20}$ have demonstrated a high caries prevalence in children who did not visit a dentist regularly.

\section{CONCLUSION}

The present study implicates that preventing dental caries still remains an enigma to the dental professional and society due to its multifactorial nature and no single risk factor can be highlighted till date in order to save children suffering from this endemic disease.

In our country, even areas having adequate dental facilities available such as Ludhiana, good regular dental attendance is low. Amazingly, caries prevalence and DMFT were also found to be high in children who regularly visited dental clinic. This could probably be attributed to other risk factors such as diet, frequency of sugar exposures, inadequate water fluoridation, brushing habits, socio-economic status, etc. for which further studies in this region is suggested.

\section{REFERENCES}

1. Lakhanpal M, Chopra A, Rao NC, Gupta N, and Vashisth S. Dietary Pattern, Tooth Brushing Habits and Caries Experience of School Children in panchkula district, India Ann Public Health Res 2014;1(1): 1001 .

2. Selwitz H. R, Ismail A.I, Pitts N.B, Dental caries Lancet 2007;369:51-59.

3. Sudha P, Bhasin S, Anegundi R. T. Prevalence Of dental caries among 5-13 year old children of manglore city J Indian Soc Pedod Prev Dent 2005.

4. Sheiham A. Prevention and control of periodontal disease. In International Conference on research into the biology of periodontal disease 1977. University of Illinois, pp. 309-86 \& Committee report pp. 369-76.

5. Frandsen A. Mechanical Oral Hygiene Practices. State of the Science Review. In Dental Plaque Control Measures and Oral 
Hygiene Practices 1986;93-116.

6. Mahalakshmi Y, Sequeira P.S and Soben P. Estimation and comparison of significant caries index and the pattern of sugar consumption among 12-year-old school going children of two different socioeconomic strata. Indian J Dent Res 2004; 15(1):20-23.

7. Boka V, Trikaliotis A, Kotsanos N and Karagiannis V. Dental caries and oral health-related factors in a sample of Greek preschool children Eur Arch Paediatr Dent 2013;14:363-368.

8. Gibson S and Williams S. Dental Caries in pre-school children: Associations with social class, tooth brushing habit and consumption of sugars and sugar containing foods. Caries Res 1999;33:101-13.

9. Tucker G.J, Andlaw R.J and Burchell C.K. The relationship between oral hygiene and dental caries incidence in 11-yearold children. Brit Dent J 1976;141:75-9.

10. Leske G.S, Ripa L.W and Barenie J.T. Comparisons of caries prevalence of children with different daily tooth brushing frequencies. Comm Dent Oral Epidemiol 1976;4(3):102-5.

11. Javali S.B and Pandit V. Statistical analysis of data related to determinants of dental caries. J Pierre Fauchard Academy 2004; 18:59-66.

12. Gupta R, Gaur K. L and Sharma.A, Zafer S, Kewalramani S. Comparison of Associating factors of Dental Caries in urban and rural children in Jaipur, (Raj) India. IOSR Journal of Dental and Medical Sciences 2013;9(3): 55-60

13. Wei S.H.Y and Hyman R.M. Paediatric Dentistry. Mosby; 1982. Chap 39.

14. Murray J.J and Rugg Gunn A.J. Fluoride in caries prevention. Bristol Wright, 1982. Quoted in Caries Res 1991;25:287-91.

15. Marthaler T.M. Explanation for changing patterns of disease in the Western World. Cariology Today, Bael Karger, 1984;1323.

16. Renson C.E, Crielaers P.J.A and Ibukunk S.A.J. et al. Changing patterns of oral health and implications of oral health manpower. Int Dent J 1985;35:235-51.

17. Pader M. Oral Hygiene Products and Practice. Marcel Dekker, New York, 1988.

18. Bellini H.T, Arneberg P. and vonder Fehr F. Oral Hygiene and Caries. A Review. Acta Odont. Scand 1981; 39:257-65.

19. Chaudhry K.P, Chawla T.N, Bhargava P.S. and Nanda R.S. Dental health survey of Lucknow school going children. J All Ind Dent Assoc 1957;29(10):199-205.

20. Miglani D.C, Sujeer V.N, Ross C and Raghupathy E. Dental Caries and its relationship to Saliva and Diet. Prevalence of Dental Caries. J Ind Dent Assoc 1970;42(9):219-24. 